\title{
FAMILY PRESERVATION SERVICES: TYPES OF SERVICES RENDERED BY SOCIAL WORKERS TO AT-RISK FAMILIES
}

\section{Marianne Strydom}

\section{INTRODUCTION}

According to the literature (Tracy, 1995:980), family preservation services are rendered in order to keep children safe in their families by stabilising the crisis situation that might necessitate removal. During intervention, social services are delivered with the aim of increasing the family's coping skills by inter alia strengthening family bonds, as well as facilitating the family's utilisation of formal and informal resources; some authors (Al, Stams, Bek, Damen, Asscher \& Van der Laan, 2012; Ryan \& Schuerman, 2004:347) maintain that this would improve the functioning of the family. These services must first focus on preventative services, then on therapeutic services and finally on statutory services (Tracy, 1995:980). Family preservation services thus entail the rendering of preventative and therapeutic services by social workers at family welfare organisations with a view to preserving the family and to preventing the removal of children by improving the family's coping skills, strengthening family bonds as well as empowering the family to utilise formal and informal resources.

South African policy documents (Department of Social Development, 2004:9, 32, 33) describe family preservation as a strategy for empowering families to allow for the optimal development of children and to prevent them being removed from their families. This premise is also embodied in legislation, since the Children's Act (Act 38 of 2005) indicates in Section 2(a) that one of the objectives of the Act is to promote the preservation and strengthening of families. To this end sections 143-149 (Act 38 of 2005) as amended (Act 41 of 2007) deal with prevention and early intervention programmes. Prevention and early intervention programmes must involve and promote the participation of families, parents, care-givers and children, identifying and seeking solutions to their problems.

From the above it is clear that social workers at child and family welfare organisations should, in accordance with policy documents and legislation, concentrate strongly on the preservation of families by focusing on preventative and early intervention services. Within this context the purpose of this article is to present a literature review of the different types of services that social workers should deliver when rendering family preservation services. It investigates the views of social workers employed by NGOs on what the term "family preservation services" means to them. The different types of services which social workers actually render as part of family preservation services to at-risk families are also described.

\section{METHODOLOGY AND RESEARCH DESIGN}

An empirical investigation was undertaken in the Western Cape Metropolitan area and its surrounds. A combination of quantitative and qualitative approaches was used (Fouché \& De Vos, 2005:133-134). This research can be classified as exploratory and descriptive research, as defined by various authors (De Vos, Strydom, Fouché \& Delport, 2002:139; Grinnell \& Williams, 1990:150), as these designs are suitable for qualitative as well as quantitative methods of research (Fouché \& De Vos, 2005:134).

The population (De Vos et al., 2002:198; Grinnell \& Williams, 1990:118) consisted of all the social workers who rendered family preservation services at non-governmental family organisations (NGOs) in the Western Cape Metropolitan and surrounding areas. Purposive 
selection according to the non-probability selection classification (De Vos et al., 2002:204, 207; Grinnell \& Williams, 1990:126,127; Strydom, 2005:201, 202) was used for sampling. Social workers who had been delivering family prevention services for at least a year were included in the study. The population consisted of $61(\mathrm{~N}=61)$ social workers.

A self-administered semi-structured questionnaire (De Vos et al., 2002:169) was used to gather quantitative and qualitative data. A deductive method (Grinnell, 1988:327-328) was followed, as the questions in the semi-structured questionnaire were based on the literature study, and applicable open and closed questions (Rubin \& Babbie, 2007:111) were developed. The semi-structured questionnaire was tested in a pilot study, so that the necessary changes could be made before data collection was undertaken (De Vos et al., 2002:172; Rubin \& Babbie, 2007:118). The questionnaires were distributed to the social workers for completion. A response of $95 \%$ was obtained from the population as $58(\mathrm{~N}=58)$ of the $61(\mathrm{~N}=61)$ respondents completed the questionnaire.

The quantitative data were processed by computer, while the qualitative data were processed by hand. The processed data provided by the respondents were discussed further by a focus group (Strydom, 2005:299,300). The advantage of using a combination of techniques (questionnaires and a focus group) is that data can be compared and similarities as well as incongruencies can be noted (Weyers, Strydom \& Huisamen, 2008:207).

Purposive selection was used to identify the participants for inclusion in the focus group (Strydom, 2005:201,202). Two social workers from each of the three organisations involved in the investigation were invited to participate in the focus group discussion. The composition of the focus group was in compliance with the criteria in the literature (Strydom, 2005:303-307) in that five or six members were considered suitable to form a focus group. All the participants were female and were involved in the delivery of family preservation services. The focus group was therefore homogenous, thus enhancing group discussions. The information generated during this two-hour discussion largely repeated or supported the data already collected from the semi-structured questionnaire, and therefore only one focus group session was held.

The focus group interview was taped and transcribed. The information obtained was used to support or further inform the data already gathered by supplying themes, sub-themes and the narratives of focus group members. All information gathered was treated as confidential in accordance with the ethical code of the social work profession.

\section{BACKGROUND TO THE STUDY}

In accordance with policy documents (Department of Social Development, 2006:29; Ministry for Welfare and Population Development: White Paper for Welfare, 1997:62) social work services must focus first on preventative services, then on early intervention services and finally on statutory services to implement a development-orientated policy for the delivery of social work services. These requirements provide structure when applied to the rendering of family preservation services.

Theoretically family preservation services include different types of services, namely family support services, family-centred services and intensive crisis services (Pecora, Fraser, Nelson, McCroskey \& Meezan, 1995:xix; Tracy, 1995:974). To distinguish between different types of services this article will utilise the exposition of the Child Welfare League of America as described in Standards for Service to Strengthen and Preserve Families with Children (1989). This exposition is still regarded as relevant in literature (Pecora et al., 1995; Tracy, 
$1995)$ and is consistent with Norman's (1985) exposition of the nature of family preservation services which should be rendered to families, as described by Berry (1997:79). These services can be depicted in pyramid form, as is presented in Figure 1.

FIGURE 1

\section{SCHEMATIC DEPICTION OF THE LEVELS AT WHICH FAMILY PRESERVATION SERVICES ARE DELIVERED}

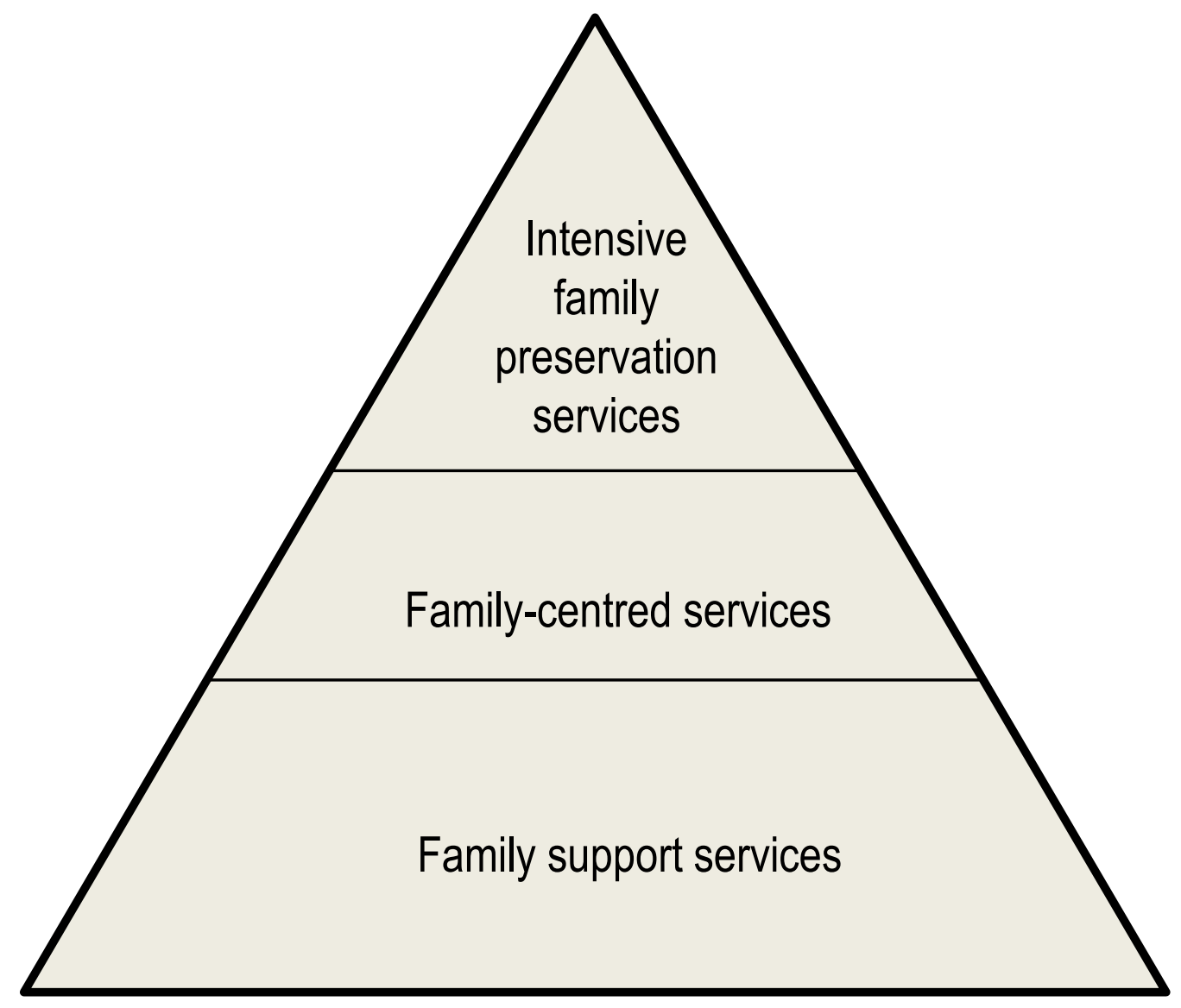

As illustrated in Figure 1, the largest part of the pyramid or the lowest level, refers to families in the general population bearing characteristics associated with the risk factors for the removal of children. Broad educational programmes and support services for parents are considered as being sufficient for the general population. Community-based support services, which include resources and supportive and educational services, must therefore be available to all members of the community to support them in their role as parents. Community-based family support services are thus aimed at preventative services or programmes.

Policy documents (Department of Social Development, 2006:29; Department of Social Development, 2004:18, 20) determine prevention to be the first or primary level at which services must be delivered in order to link families to resources, to build their capacity and to reduce risk behaviour. Experts emphasise the advantages of family support services that focus on giving families access to services, resources or networks in the community in order to ensure that the children of at-risk families remain within the family and thereby avoid the need for statutory services (Chaffin, Bonner \& Hill, 2001; Jack, 1997; Nair, Blake \& Vosler, 1997; Pithouse \& Tasiran, 2000; Warren-Adamson, 2006). Examples of such services are parent 
education programmes, family support services such as feeding schemes, play groups, and school- or community-based resource centres (Armstrong \& Hill, 2001:351; Cole, 1995:165; Pierson, 2004:81; Tracy, 1995:974).

The second or middle part of the pyramid (Figure 1) refers to families where there is a risk that the children might have to be removed, but where they are not in danger. As the children are not in danger, less intensive services are delivered to these families, which typically include family-centred and home-based services, as well as family support services. Family-centred services such as counselling and educational services must be made available to families experiencing problems that could impair their stability.

Family-centred services are linked to the second level of service delivery, as prescribed by the ISDM (2006). At this level early intervention services (therapeutic services) should be delivered to at-risk families to exclude the need for statutory action (Department of Social Development, 2006:29; Department of Social Development, 2004:18). This entails intervention, usually for a longer period (6 months or longer) and is rendered during office interviews and/or home visits. Through these services an attempt is made to prevent the family's problems and needs from reaching crisis proportions. The intervention consists of therapeutic services like counselling and educational services such as the development of skills in family members (Cash \& Berry, 2003:13; Cash, 2001:44; Juby \& Rycraft, 2004:585; Martens, 2009:12; Mullins, Cheung \& Lietz, 2011).

These types of services are also consistent with the approach in the Children's Act (Act 38 of 2005) as amended (Act 41 of 2007) in which sections 143 to 149 prescribe the content of preventative and early intervention programmes. Section 144 determines that the focus of these programmes must be on maintaining the family structure, on the development of parenting skills, as well as the development of interpersonal relationships in the family.

In addition to intervention of an educational and therapeutic nature, concrete services are also rendered in the interest of family preservation. Examples of these services include assisting the family to obtain housing, with provision of food and clothing, and arranging that the family members attend life skills programmes or helping them to gain access to community-based resources (Maluccio, Pine \& Tracy, 2002:152,153; Mullins et al., 2011; Parton \& Matthews, 2001:101; Tracy, 1995:974). These types of services are consistent with the approach described in the South African Children's Act (Act 38 of 2005) as amended (Act 41 of 2007), where section 144 (2) states, among other things, that prevention and early intervention programmes can also include the following services: assisting families to obtain the basic necessities of life or empowering families to obtain such necessities for themselves, as well as providing families with information to enable them to gain access services.

The top part of the pyramid in Figure 1 refers to families that are experiencing a crisis and where the removal of children is imminent, signifying that intensive family-centred crisis services or intensive family preservation services must be made available to families (Berry, Cash \& Brook, 2000:191; Lietz, 2009:1338; Tracy, 1995:974,975). Service delivery is then focused on the immediate crisis of the family and is aimed at the restitution of the functioning of the family to an acceptable minimum level to prevent removal of the children. Intensive crisis services can thus also be delivered at the second level of service rendering in accordance with the ISDM (Department of Social Development, 2006:29) as part of familycentred services to avoid statutory services. According to several American authors (Berry, Cash \& Brook, 2000:191; Martens, 2009:8; Pecora et al., 1995:xix; Tracy, 1995:974), these 
services are rendered on a short-term basis (0-3 months) to families experiencing a crisis threatening the removal of a child because of possible child abuse and/or neglect. The service requires that social workers work with small case loads (approximately 2-6 families), are available 24 hours a day, and make use of mostly home visits for intervention. Concrete services, as in the case of family-centred services, are also delivered.

The difference between family-centred and intensive family preservation services is mainly that the imminent removal of a child demands intensive services, while this is not the case with family-centred services. However, in the case of family-centred services there are indeed risk factors for child abuse and neglect, which makes these services indispensable. Children in need of child protection require both types of services.

The White Paper for Welfare (Ministry for Welfare and Population Development, 1997:66) states that service rendering to families in South Africa must be aimed at prevention by improving family functioning before child protection services become necessary. Child protection is, according to September and Blankenberg $(2004: 4,9,10)$, the greatest focus area in the delivery of child and family welfare services in South Africa. Where child protection services come into effect, intensive family preservation services or crisis services are, according to some authors (Berry, 1997:50,51; Martens, 2009; Tracy, 1995:980), one type of service that should be delivered, especially when the removal of children is imminent.

If crisis services are not successful, statutory services must be delivered, requiring the children to be removed from the family. This is the third level at which services can be delivered (Department of Social Development, 2006:29; Department of Social Development, 2004:22).

From the above discussion it is clear that the different types of services that must theoretically be delivered for family preservation are in accordance with the requirements for social work service delivery as stipulated in the ISDM (Department of Social Development, 2006), the White Paper for Welfare (Ministry for welfare and population development, 1997), as well as the Children's Act (Act 38 of 2005) as amended (Act 41 of 2007). Family preservation services thus entail that preventative or family support services, early intervention services or familycentred services, and intensive crisis services should be delivered to families according to their needs. Another important aspect is that the literature (Chaffin et al., 2001:288; O'Reilly, Wilkes, Luck \& Jackson, 2012:90) indicates that a combination of the above-mentioned types of family preservation services should be delivered to families for intervention to be effective.

\section{RESULTS OF THE STUDY}

The results of the study are explained with reference to the research questions, which were mainly aimed to determine:

- The perspective of the social workers on what the term "family preservation services" means to them; and

- The nature or extent of the family-centred family preservation services that are delivered to families by social workers at family welfare organisations.

\section{PROFILE OF THE RESPONDENTS}

\section{PROFILE OF RESPONDENTS AND FOCUS GROUP MEMBERS}

Family preservation services were delivered mostly by young adult workers, because most (28) of the respondents $(n=58)$ were aged between 23 and 29 . The majority $(50=86.2)$ of the 
respondents also had between one and four years' work experience; $35(=60.3 \%)$ of the respondents had a case load of 100 to 299 families. It is clear that the respondents at the family welfare organisations included in this study often have large case loads, confirming other South African research findings (September \& Blankenberg, 2004:28,29) where case loads often varied between 150 and 300 cases.

\section{DESCRIPTION OF FAMILY PRESERVATION SERVICES}

As policy documents indicate that family preservation services should be rendered, respondents were asked to describe their understanding of the term "family preservation services", so that their perspective could be determined.

These descriptions were analysed against the prescribed descriptions of the concept relating to family preservation services. According to the latter, family preservation services include preventative and therapeutic services that should be delivered by social workers at family welfare organisations with the aim of preserving the family and preventing the removal of children from their families by improving coping skills in the families, strengthening family bonds and empowering the family to fully utilise formal and informal resources (Tracy, 1995).

For the purpose of analysis, this description of the concept of family preservation was divided into three areas, namely the purpose of the service delivery, the nature of service delivery as well as the types of services rendered. The data are presented in Table 1.

TABLE 1

DESCRIPTION OF WHAT THE TERM "FAMILY PRESERVATION SERVICES" MEANS TO RESPONDENTS

\begin{tabular}{|l|r|}
\hline DESCRIPTION OF THE TERM "FAMILY PRESERVATION SERVICES” & f (\%) \\
\hline Purpose of services & $20(34.5 \%)$ \\
Family preservation & $10(17.2 \%)$ \\
Prevent the removal of children & $10(17.2 \%)$ \\
\hline Nature of service delivery & $6(10.3 \%)$ \\
Preventative or support services & $2(3.4 \%)$ \\
Therapeutic services & \\
Strengths based & $5(8.6 \%)$ \\
\hline Types of services: Skills development & $3(5.1 \%)$ \\
Improve skills & $1(1.7 \%)$ \\
Improve parenting skills & $2(3.4 \%)$ \\
Strengthen communication & $4(6.9 \%)$ \\
Strengthen family bonds & $7(12.0 \%)$ \\
\hline Types of services: Empower the family to use resources & \\
Empower families & $9(15.5 \%)$ \\
Make use of resources & \\
\hline Non-specific responses & $11(18.9 \%)$ \\
\hline Optimal functioning of families & \\
\hline Inappropriate responses & \\
Reunify families & \\
\hline
\end{tabular}




\section{PURPOSES OF SERVICE DELIVERY}

It can be seen from Table 1 that $20(34.48 \%)$ of the respondents are of the opinion that the term "family preservation services" means that the family must be preserved through the delivery of these services, while for $10(17.24 \%)$ of the respondents it refers to actions preventing the removal of children from the family. A total of 31 (53.4\%) of the respondents, amounting to just more than half of the group, could thus identify the purpose of family preservation, which is consistent with the literature (Ryan \& Shuerman, 2004:347; Tracy, 1995:980).

\section{THE NATURE OF SERVICE DELIVERY}

Regarding the nature of services, the term "family preservation" to most $(40=68 \%)$ of the respondents in this study did not clearly indicate that preventative and therapeutic social work services should be delivered to the family, nor that the focus should be on the strengths of the family, as described in literature (Pecora et al., 1995:xix; Tracy, 1995:980). Only 18 (31\%) of the respondents indicated that the focus should be on these services.

\section{TYPES OF SERVICES RENDERED: SKILLS DEVELOPMENT}

Fewer than a fifth $(11=18.9 \%)$ of the respondents associated the development of the skills of family members with their perception of "family preservation". Skills development is considered by many authors (Mullins et al. 2011; Cash \& Berry, 2003:5; Dawson \& Berry, 2002:298,299; Tracy, 1995:980) to be one of the most important services that should be delivered to at-risk families as part of family preservation.

\section{TYPES OF SERVICES RENDERED: EMPOWERING THE FAMILY TO MAKE USE OF RESOURCES}

The fact that family preservation services must empower families to make use of available resources was mentioned by a small number $(11=18.9 \%)$ of the respondents in relation to "family preservation". In line with the literature (Berry, 1997:144; Cash, 2001:51; Juby \& Rycraft, 2004:585; MacDonald, 2005:285; Tracy, 1995:980), it is concluded that the respondents in this study did not associate the empowerment of family members to utilise resources with their perception of "family preservation".

\section{NON-SPECIFIC RESPONSES}

Nine $(15.5 \%)$ of the respondents described "family preservation" as the delivery of services in order to help the family function optimally. In this study optimal functioning is considered to be a broad concept, as social work service delivery is generally directed towards the optimal functioning of individuals, families, groups and communities. These responses can indicate that respondents are uncertain about what "family preservation" means to them.

\section{INAPPROPRIATE RESPONSES}

Fewer than a fifth $(11=18.9 \%)$ of the respondents indicated that in their opinion, "family preservation services" means to re-unite families after removal of children has taken place. This shows that for some respondents "family preservation" does not convey the original meaning of the term as described in the literature (Pecora et al., 1995:xix; Tracy, 1995:980).

\section{NATURE OF FAMILY-CENTRED SERVICES RENDERED TO FAMILIES}

Family-centred family preservation services require social workers to deliver concrete, educational and therapeutic services to families in order to prevent the removal of children 
442

from those families. There was an attempt to determine the nature of family-centred services that social workers deliver to families.

\section{CONCRETE SERVICES}

The respondents were asked to indicate on a four-point scale how often certain concrete services were delivered to at-risk families in their case load in order to prevent statutory services. The findings are presented in Table 2.

TABLE 2

THE REGULARITY OF THE DELIVERY OF CONCRETE SERVICES TO PREVENT REMOVAL OF CHILDREN

\begin{tabular}{|c|c|c|c|c|c|c|}
\hline \multirow{4}{*}{ CONCRETE SERVICES } & \multicolumn{6}{|c|}{ OCCURRENCE } \\
\hline & Always & Often & Seldom & Never & & Total \\
\hline & 1 & 2 & 3 & 4 & compictea & $\mathbf{N}(\%)$ \\
\hline & $f(\%)$ & $\mathbf{f}(\%)$ & $f(\%)$ & $f(\%)$ & $f(\%)$ & \\
\hline $\begin{array}{l}\text { Help with the housekeeping e.g. } \\
\text { Helping families do shopping }\end{array}$ & $1(1.7 \%)$ & $2(3.4 \%)$ & $20(34.5)$ & $32(55.2)$ & $3(5.2)$ & $58(100)$ \\
\hline $\begin{array}{l}\text { Development of homemaking } \\
\text { skills in caretakers e.g. the } \\
\text { planning and preparation of meals } \\
\text { through modelling in the home }\end{array}$ & $1(1.7)$ & $5(8.6)$ & $20(34.5)$ & $30(51.7)$ & $2(3.4)$ & $58(100)$ \\
\hline $\begin{array}{l}\text { Practical arrangements for: } \\
\text { Transport of family members }\end{array}$ & $3(5.2)$ & $13(22.4)$ & $28(48.3)$ & $13(22.4)$ & $1(1.7)$ & $58(100)$ \\
\hline $\begin{array}{l}\text { Care of children by other members } \\
\text { of the community or by } \\
\text { institutions }\end{array}$ & $8(13.8)$ & $36(62.1)$ & $9(15.5)$ & $4(6.9)$ & $1(1.7)$ & $58(100)$ \\
\hline $\begin{array}{l}\text { Provision of material assistance } \\
\text { e.g. } \\
\text { Food }\end{array}$ & $14(24.1)$ & $37(63.8)$ & $3(5.2)$ & $4(6.9)$ & $0(0.0)$ & $58(100)$ \\
\hline Financial assistance & $2(3.4)$ & $11(19.0)$ & $31(53.4)$ & $14(24.1)$ & $0(0.0)$ & $58(100)$ \\
\hline $\begin{array}{l}\text { Referral to other community- } \\
\text { based resources }\end{array}$ & $19(32.8)$ & $34(58.6)$ & $3(5.2)$ & $2(3.4)$ & $0(0.0)$ & $58(100)$ \\
\hline $\begin{array}{l}\text { Accompanying family members } \\
\text { to resources }\end{array}$ & $0(0.0)$ & $21(36.2)$ & $28(48.3)$ & $7(12.1)$ & $2(3.4)$ & $58(100)$ \\
\hline $\begin{array}{l}\text { Other (specify)): } \\
\text { Acquiring birth certificate }\end{array}$ & $0(0.0)$ & $1(1.7)$ & $0(0.0)$ & $0(0.0)$ & $57(98.3 \%)$ & $58(100)$ \\
\hline $\begin{array}{l}\text { Provision of clothing. school } \\
\text { uniforms }\end{array}$ & $0(0.0)$ & $1(1.7)$ & $0(0.0)$ & $0(0.0)$ & $57(98.3 \%)$ & $58(100)$ \\
\hline
\end{tabular}

$\mathrm{N}=58$

\section{- Referral to other community-based resources}

According to Table 2 referral to other community-based resources is the service delivered most regularly, as $19(32.8 \%)$ of the respondents always deliver this service and $34(58.6 \%)$ often deliver the service. This finding accords with the literature (Cash, 2001:51; Thompson, 1995:150; Warren-Adamson, 2006:172), where referrals to other community-based resources is seen as an important aspect of concrete service delivery, facilitating further support to the family. 


\section{- Provision of material support}

The majority of the respondents indicated that the provision of food as a concrete service was delivered often $(37=63.6 \%)$ or always $(14=24.1 \%)$, but it seems that financial assistance takes place less often. The majority of the respondents $(31=53.4 \%)$ indicated that financial assistance was seldom or never $(14=24 \%)$ given.

The fact that food is regularly provided is in accord with Kruger's (1996:122,123) South African study of the delivery of intensive family preservation services, where it was found that social workers usually give concrete help by providing food parcels. Financial assistance is probably provided less often, because organisations do not have sufficient funds; this affirms the findings of other South African researchers (Brown \& Neku, 2005:308), where organisations indicated that they do not always have the resources to provide the clients with food. This finding contradicts the findings reported in international literature (Berry et al., 2000:197; Cash \& Berry, 2003:4; Lietz, 2009:1402, 1405), where financial assistance and the provision of food are regarded as concrete services delivered on an ongoing basis.

\section{- Making practical arrangements}

Most of the respondents stated that in addition to providing food, they often $(36=62.1 \%)$ or always $(8=13.8 \%)$ make arrangements for the care of children by other members of the community or by institutions. With regard to transporting family members to resources and services, it seems that this concrete service is not often provided, as respondents say that they seldom $(28=48.3 \%)$ or never $(13=22.4 \%)$ do so. This finding does not agree with the research of Berry et al. (2000) in the USA, where it was found that the concrete service provided most often was arranging for the transport of family members (64\%), whereas arranging for the care of children was done less often (52\%). Ryan and Schuerman's (2004:352) study also found that the concrete service most often provided per family was transport. A probable explanation for the fact that transport arrangements are not often provided as reported in this study is that respondents do not have sufficient time (high case loads) to make these arrangements, or that they do not have sufficient resources. In other South African research (Brown \& Neku, 2005:308; Strydom, 2010:198) social workers indicated that a lack of such resources as vehicles in the organisation hampered service delivery. Furthermore the communities where social workers in South Africa render services often do not have at their disposal the resources or volunteers who can provide this transport.

\section{- Accompanying family members to resources}

Although the majority $(28=48.3 \%)$ of the respondents indicated that they seldom or never $(7=3.4 \%)$ accompany family members to resources, a significant number $(21=36.2 \%)$ of them indicated that this type of concrete service is often rendered. In the intensive family preservation pilot project which was undertaken in South Africa (The Inter-Ministerial Committee on Young People at Risk, 1998:27,30) child care workers engaged to accompany family members to resources. It would therefore seem that there is a need in South Africa for this type of service.

\section{- Assistance with the maintenance of the household}

Table 1 clearly shows that concrete services such as helping families do their shopping or developing home-maker skills such as the planning or preparation of meals, by modelling in the home, are never $(30=51.7 \%)$, or seldom $(20=34.4 \%)$ rendered. 
The finding that most respondents seldom or never assist families with maintenance of the household contrasts with the nature of concrete services rendered by respondents in the USA. Some authors (Berry, 1997:145,149,150; Martens, 2009:12; Smith, 1995:13) indicate that concrete services directly associated with the management of the household, such as developing a daily routine and helping families with shopping and the preparation of meals, are examples of services that should be rendered mainly by the social workers.

Respondents involved in this investigation probably do not have sufficient time for this type of service because of their high case loads. An aspect that warrants further investigation is whether the respondents are aware of the importance of these types of concrete services in promoting family preservation.

\section{- Other concrete services that are rendered}

Only two (3.4\%) respondents listed other concrete services (other than indicated in Table 2), namely the provision of clothing and helping to acquire a birth certificate for children, both of which are often done. The provision of clothing and other household articles such as curtains, was found in Kruger's $(1996: 122,123)$ study in the Western Cape to be the form of concrete help least given. The respondents in this study also did not indicate it as another form of service delivery.

From the above discussion it is clear that most concrete services listed in this investigation are rendered seldom or never, rather than always or often. Concrete services delivered to at-risk families towards improving family preservation, are thus very limited. This finding is important as a balance needs to be struck between concrete and therapeutic services (Maluccio et al., 2002:154), as families cannot be expected to develop relationship skills and to manage behavioural problems in the midst of environmental stressors such as a lack of food, clothes and other means of existence (Berry, 1997:145; Cash \& Berry, 2001:4; Maluccio et al., 2002:153), as concrete support provides a solution to the daily survival problems (Mullins et al., 2011). It further seems that, according to certain studies (Littell \& Tajima; 2000:426,428; Mullins et al., 2011), participation by parents is greater when a wide range of concrete services and intercession (mediation) by social workers are available. For example, Ryan and Schuerman (2004:362) found that concrete services such as providing clothes and other supplies decreased the risk of subsequent child abuse in families where there were financial problems. In Lietz's $(2009: 1402,1405)$ study on whether families perceived themselves as stronger after family-centred services had been rendered, it was found that concrete services (the provision of food, nappies, financial assistance) that enabled families to satisfy their basic needs had the strongest influence on families. Concrete services were also considered essential by these families to support the process of change.

\section{PERSPECTIVE ON THE DELIVERY OF CONCRETE SERVICES}

The indication by respondents that only limited concrete services were rendered was explored further by the participants in the focus group discussion. Participants conveyed their perspective on how the concrete service rendering such as accompanying family members to resources and assisting them with home-making skills appeared in their organisations. The narratives of the participants were investigated and organised into sub-themes and categories, as indicated in Table 3. 
TABLE 3

\section{PERSPECTIVES ON THE DELIVERY OF CONCRETE SERVICES AT ORGANISATIONS}

\begin{tabular}{|c|c|c|}
\hline \multicolumn{3}{|c|}{ THEME: DELIVERY OF CONCRETE SERVICES } \\
\hline SUB-THEMES & CATEGORIES & NARRATIVES \\
\hline \multirow[t]{2}{*}{$\begin{array}{l}\text { 1. Lack of time } \\
\text { to render } \\
\text { concrete } \\
\text { services }\end{array}$} & $\begin{array}{l}\text { 1. Statutory case } \\
\text { load too high }\end{array}$ & $\begin{array}{l}\text { - "In our community the statutory work load is too high, so } \\
\text { there is simply not enough time to try to begin with such } \\
\text { projects... One does not want to say that these are less } \\
\text { important, but if there was not so much statutory work..." } \\
\text { "'In ons gemeenskap is statutêre werk baie hoog so daar is } \\
\text { net eenvoudig nie die tyd om te poog om sulke tipe van } \\
\text { projekte te begin nie. 'n Mens wil nie sê dis minder } \\
\text { belangrik nie, maar as die statutêre werk nie so hoog was } \\
\text { nie...') }\end{array}$ \\
\hline & $\begin{array}{l}\text { 2. Limited } \\
\text { concrete } \\
\text { services are } \\
\text { rendered }\end{array}$ & $\begin{array}{l}\text { - "I can still do such practical things like dropping off, but I } \\
\text { cannot do more than that" ("Ek kan sulke praktiese goed } \\
\text { nog doen, soos aflaai en so aan, maar ek kan nie meer as dit } \\
\text { doen nie.") } \\
\text { - "One must sometimes help with transport, I mean if the } \\
\text { situation requires this, or if there is no progress or if } \\
\text { nobody does anything, then you must do it yourself, so we } \\
\text { will transport people to register their children's births as } \\
\text { they just don't do it and you need the documents. Our } \\
\text { clients often have a problem with transport, so if you want } \\
\text { them to come, you must fetch them." ("Mens moet nog } \\
\text { partykeer help met vervoer, ek meen as die situasie so is, } \\
\text { dat daar nie vordering gemaak word nie, of niemand 'n ding } \\
\text { doen nie, dan moet jy dit maar self doen, so ons sal mense } \\
\text { ry om hulle kinders se geboorte te registreer, want hulle } \\
\text { kom net nie so ver nie en jy het miskien die dokumente } \\
\text { nodig, ... ons kliënte het dikwels 'n probleem met vervoer, } \\
\text { so as jy wil hê hulle moet kom, moet jy hulle aanry.") }\end{array}$ \\
\hline $\begin{array}{l}\text { 2. Unaware of the } \\
\text { importance of } \\
\text { concrete } \\
\text { services }\end{array}$ & $\begin{array}{l}\text { 1. Ignorance of } \\
\text { the nature of } \\
\text { services }\end{array}$ & $\begin{array}{l}\text { - "I do not know, but in my post it is a waste of time . It is } \\
\text { based on the old social work. Now it is a waste of time." } \\
\text { ("Ek weet nie, maar in my pos is dit tydmors. Dis gebaseer } \\
\text { op die ou maatskaplike werk. Dis nou 'n waste of time.") } \\
\text { - "...To help with homemaker skills, to look for the little } \\
\text { potential there is inside the home, just to be nice, no I can't } \\
\text { do that". ("...om tuisteskepper-vaardighede of die bietjie } \\
\text { potensiaal wat daar binne die huishouding is te ontgin, } \\
\text { sommer net om nice te wees, ek kan nie".) }\end{array}$ \\
\hline
\end{tabular}

\section{LACK OF TIME FOR CONCRETE SERVICE-RENDERING}

The first theme refers to a lack of time to render concrete services. Two categories were identified in this sub-theme. In the first category, members of the focus group are of the opinion that work loads, and specifically statutory loads, are too heavy. This lack of time is also associated with the shortage of social workers to render the services. It was found that the shortage of social workers hampered the delivery of concrete services. This shortage of social 
workers is repeatedly highlighted in the South African literature (Brown \& Neku, 2005:308; Lombard \& Kleyn, 2006:225; September \& Blankenberg, 2004:29; September, 2007:43).

The second category confirms the finding already made in the previous section, namely that a limited number of concrete services are delivered. Only a few concrete services are rendered in emergency cases, e.g. transporting family members. Restrictions in the delivery of concrete services can mean that the working relationship between the social worker and the family can be affected, while the active involvement of the family in service rendering is also not encouraged (Cash \& Berry, 2003:4; Lietz, 2009:1405; Maluccio et al., 2002:153). Where concrete services are not delivered, the stress which the family is experiencing is not lessened (Juby \& Rycraft, 2004:585).

\section{UNAWARE OF THE IMPORTANCE OF CONCRETE SERVICE DELIVERY}

The second sub-theme to emerge is that members of the focus group were unaware of the importance of concrete service delivery. The only category to be identified concerns ignorance about the nature of concrete service delivery, as it is considered a waste of time, or a service delivered just to be friendly. This confirms an earlier finding in this investigation, namely that respondents are unsure about the services that should be rendered when the focus is on family preservation. Respondents as well as members of the focus group seem to be unaware of the advantages of concrete service delivery, for example, that these services can, among other things, help to motivate the family to participate in therapeutic services (Berry, 1997:150,152, 154), as well as improve the relationship between the social worker and the family (Lietz, 2009:1405). They also seem unaware of the fact that paraprofessional staff or volunteers can be engaged to render the services.

An aspect that warrants further investigation is whether the study group had formal education at their respective training institutions or welfare organisations in the delivery of family preservation services. Although the study group members have heavy caseloads, this cannot be seen as the only reason for the lack of concrete service delivery, as they were uncertain about the purpose and nature as well as the types of family preservation services that should be rendered.

\section{EDUCATIONAL AND ENABLING SERVICES}

Educational and enabling services focus on the development of skills in at-risk families to empower them to make use of resources in the community on their own. Therefore the respondents were asked to indicate on a four-point scale how regularly certain educational and enabling services were rendered to clients on their case loads. The responses are shown in Table 4.

It is clear from Table 4 that the respondents in this investigation concentrated more strongly on the development of life skills than on involving family members in community-based resources. Services relating to the development of life skills are delivered often and regularly, while linking family members to community resources is done often rather than seldom. These aspects are analysed below. 
TABLE 4

REGULARITY OF DELIVERY OF EDUCATIONAL AND ENABLING SERVICES IN ORDER TO PREVENT STATUTORY SERVICES

\begin{tabular}{|c|c|c|c|c|c|c|}
\hline \multirow{4}{*}{$\begin{array}{c}\text { EDUCATIONAL AND } \\
\text { ENABLING SERVICES }\end{array}$} & \multicolumn{6}{|c|}{ OCCURRENCE } \\
\hline & Always & Often & Seldom & Never & $\begin{array}{c}\text { Not } \\
\text { completed }\end{array}$ & Total \\
\hline & 1 & 2 & 3 & 4 & & \\
\hline & $\mathbf{f}(\%)$ & $\mathbf{f}(\%)$ & $f(\%)$ & $\mathbf{f}(\%)$ & $\mathbf{f}(\%)$ & $\mathbf{n}(\%)$ \\
\hline $\begin{array}{l}\text { Improving skills such as: } \\
\text { Parenting skills }\end{array}$ & $16(27.6)$ & $35(60.3)$ & $4(6.9)$ & $2(3.4)$ & $1(1.7)$ & $58(100)$ \\
\hline Financial planning skills & $4(6.9)$ & $22(37.9)$ & $20(34.5)$ & $9(15.5)$ & $3(5.2)$ & $58(100)$ \\
\hline Communication skills & $21(36.2)$ & $30(51.7)$ & $5(8.6)$ & $1(1.7)$ & $1(1.7)$ & $58(100)$ \\
\hline Problem-solving skills & $25(43.1)$ & $30(51.7)$ & $1(1.7)$ & $1(1.7)$ & $1(1.7)$ & $58(100)$ \\
\hline Conflict management skills & $23(39.7)$ & $29(50.0)$ & $2(3.4)$ & $1(1.7)$ & $3(5.2)$ & $58(100)$ \\
\hline $\begin{array}{l}\text { Involving families in: } \\
\text { Informal support groups, e.g. } \\
\text { neighbours, clubs }\end{array}$ & $3(5.2)$ & $25(43.1)$ & $24(41.4)$ & $1(1.7)$ & $5(8.6)$ & $58(100)$ \\
\hline $\begin{array}{l}\text { Formal support resources, e.g. } \\
\text { Day care }\end{array}$ & $8(13.8)$ & $24(41.4)$ & $16(27.6)$ & $6(10.3)$ & $4(6.9)$ & $58(100)$ \\
\hline Play groups & $5(8.6)$ & $21(36.2)$ & $17(29.3)$ & $7(12.1)$ & $8(13.8)$ & $58(100)$ \\
\hline Weekly support groups & $4(6.9)$ & $9(15.5)$ & $15(25.9)$ & $9(15.5)$ & $21(36.2)$ & $58(100)$ \\
\hline $\begin{array}{l}\text { Other } \\
\text { Parent guidance groups }\end{array}$ & & $1(1.7)$ & & & & \\
\hline
\end{tabular}

$\mathrm{N}=58$

\section{- Improving life skills}

In the area of life skills the improvement of problem-solving skills is the service rendered most often. Twenty-five (43.1\%) of the respondents render this service always and $30(51.7 \%)$ of the respondents deliver it often. The improvement of conflict management skills is next on the list as $23(39.7 \%$ of the respondents always deliver this service and $29(50 \%)$ deliver it often. The improvement of parenting skills is also a service rendered regularly. Sixteen (26.6\%) of the respondents always deliver this service and 35 (60.3\%) often. Education regarding communication skills is also given often $(30=51.7 \%)$ and always $(21=36.5 \%)$.

The improvement of financial planning services is the only educational service that is rendered often $(22=37.9 \%)$ or seldom $(20=34.5 \%)$. It was also the service that most $(9=15.5 \%)$ respondents never rendered.

The strong emphasis that the respondents place on the improvement of life skills confirms the view held in the international literature (Dawson \& Berry, 2002:298,299; Fraser, Nelson \& Rivard, 1997:145; Lietz, 2009:1401-1402; Thompson, 1995:150) that social workers focus on life skills development in delivering educational and enabling services.

\section{- Engagement of family members to make use of informal and formal resources}

Table 4 indicates that the respondents in this study group seldom engage family members to make use of formal and informal resources. In this category the engagement of family members with informal resources of support like neighbours and clubs is the service delivered most regularly, namely often $(25=43.1 \%)$ or seldom $(24=41.4 \%)$. 
Regarding the involvement of family members in formal support resources such as day care and playgroups, it also seems that most respondents render these services often or seldom. Weekly support groups for at-risk families is apparently the enabling service rendered least often, as the majority of the respondents indicated that this service was rendered seldom $(15=25.5 \%)$, or never $(9=15.5 \%)$. A considerable number of respondents $(21=36.2 \%)$ did not complete this section, which could imply that they do not know what a support group entails.

Altogether more respondents also indicated that the engagement of family members with informal and semi-formal resources never $(23=39.6 \%)$, took place, other than in the case of the improvement of life skills $(14=24.1 \%)$. The total number of respondents that did not complete the sections on the improvement of life skills was nine $(15.5 \%)$, while $38(65.5 \%)$ respondents did not complete certain sections dealing with the engagement of family members with resources. It was found that the respondents were more sure about how regularly they focused on improving life skills than about how regularly they focused on the expansion of families' networks by connecting them with resources.

The fact that families are less often connected with resources, is an important finding, for the following reasons. If it is not possible to expand the family's informal resources, then service rendering will have to be focused more strongly on connecting the family with semi-formal and formal resources to promote family preservation. This form of social support means that the family is empowered to enter into the existing programmes in the organisation or in the community which can provide support (Berry, 1997:144,145; Cash, 2001:51) such as day care, play groups and weekly support groups. The literature (Armstrong \& Hill, 2001; Lietz, 2009:1338; Van Puyenbroeck, Loots, Grietens, Jacquet, Vanderfaeillie, Escuderos, 2009:229) emphasises the advantages of services that focus on connecting family members with services, resources or networks in the community in order to keep children in at-risk families.

\section{- Other educational and enabling services}

Only one respondent (1.7\%) indicated a parent-guidance group as an educational and enabling service that was rendered. It can be deduced that respondents do not render services other than those described above.

\section{THERAPEUTIC SERVICES}

Therapeutic services are an important component of both family-centred and intensive family preservation or crisis services. In Table 5 respondents indicate on a scale of 1 to 4 how often they render therapeutic services to at-risk families in their case load.

\section{- Short-term family-centred services}

Table 5 shows that short-term family-centred intervention is the service rendered most often. The majority of the respondents always $(21=36.2 \%$ deliver this service and often $(30=51.7 \%)$. The minority of the respondents $(6=10.3 \%)$ deliver this service seldom $(5=8.6 \%)$ or never $(1=1.7 \%)$. 
TABLE 5

REGULARITY OF DELIVERY OF THERAPEUTIC SERVICES TO PREVENT THE REMOVAL OF CHILDREN

\begin{tabular}{|c|c|c|c|c|c|c|}
\hline \multirow{4}{*}{ THERAPEUTIC SERVICES } & \multicolumn{6}{|c|}{ OCCURRENCE } \\
\hline & Always & Often & Seldom & Never & & Total \\
\hline & 4 & 3 & 2 & 1 & & \\
\hline & $f(\%)$ & $f(\%)$ & $f(\%)$ & $f(\%)$ & $f(\%)$ & $\mathbf{n}(\%)$ \\
\hline $\begin{array}{l}\text { Short-term family-centred services } \\
\text { such as: } \\
\text { Crisis intervention }\end{array}$ & $21(36.2)$ & $30(51.7)$ & $5(8.6)$ & $1(1.7)$ & $1(1.7)$ & $58(100)$ \\
\hline $\begin{array}{l}\text { Long-term family-centred services } \\
\text { such as: } \\
\text { Family counselling }\end{array}$ & $16(27.6)$ & $32(55.2)$ & $5(8.6)$ & $1(1.7)$ & $4(6.9)$ & $58(100)$ \\
\hline Marriage counselling & $9(15.5)$ & $27(46.6)$ & $17(29.3)$ & $3(5.2)$ & $2(3.4)$ & $58(100)$ \\
\hline Substance abuse counselling & $20(34.5)$ & $26(44.8)$ & $9(15.5)$ & $2(3.4)$ & $1(1.7)$ & $58(100)$ \\
\hline $\begin{array}{lll}\text { Counselling } & \text { regarding } & \text { domestic } \\
\text { violence }\end{array}$ & $10(17.2)$ & $34(58.6)$ & $12(20.7)$ & $1(1.7)$ & $1(1.7)$ & $58(100)$ \\
\hline $\begin{array}{l}\text { Other: } \\
\text { Mediation } \\
\text { Counselling children after the death } \\
\text { of parents }\end{array}$ & & $1(1.7)$ & $1(1.7)$ & & $56(96.6)$ & $58(100)$ \\
\hline
\end{tabular}

$\mathrm{N}=58$

The finding that short-term family-centred services such as crisis intervention are rendered most often is consistent with the characteristics of intensive family preservation services. An important characteristic of intensive family preservation services is that this service is delivered to families in crisis (Berry, 1997:76,79; Littell \& Tajima, 2000:406; Thompson, 1995:147), where the risk that children will be removed is high (Fraser et al., 1997:140; Martens, 2009:8) as a result of neglect or abuse of the children (Berry, 1997:137; Martens, 2009:8). Intensive family preservation services are considered to be the last type of service rendered to the family before the child is removed (Thompson, 1995:148; Tracy, 1995:976).

The regular delivery of crisis services must also be seen in the light of the fact that the average case load of social workers in this study group is large. Because of large case loads, the respondents could be forced to work in a crisis-orientated way, which means that intensive family preservation services as described in literature (Martens, 2009; Tracy, 1995) are not delivered. Smaller case loads are also associated with more positive outcomes regarding intervention. As maintained in the literature (Cash \& Berry, 2003:22; Forrester, Copello, Waissbein \& Pokhrel, 2008:425; Thompson, 1995:154), the impact of social problems linked to poverty such as unemployment, health and social inequality are so immense on children and families, that it cannot be addressed by short-term crisis services.

\section{- Long-term family-centred services}

With regard to longer-term family-centred services, respondents in this study delivered the following services on a regular basis, from those rendered most often to those rendered least often: substance abuse counselling, family counselling, counselling with regard to the handling of domestic violence, and lastly marriage guidance. The longer-term therapeutic service rendered most often is substance abuse counselling, as $20(34.5 \%)$ of the respondents always render this service, and $26(44.5 \%)$ deliver it often. This service is long term in nature 
(Forrester et al., 2008:435; Semidei, Feig-Radel \& Nolan, 2001:12), as substance abuse in combination with child neglect requires years of counselling (Wilson \& Horner, 2005:476). The case loads at family organisations that render substance abuse counselling can thus increase. However, the study by Lietz (2010:140) found that family members experienced substance abuse counselling, or referrals to institutions which focus on these services, as crucial to their change.

After substance abuse counselling, family counselling is the therapeutic service rendered most often. Thirty-two respondents $(55.2 \%)$ often render this service and $16(27.6 \%)$ always. This finding that family counselling as a therapeutic service is rendered regularly is consistent with the research finding of Ghate and Hazel (2002:76) in the United Kingdom, where it was found that at-risk families continuously experience problems in relationships with their spouses and children. Research (Jones, Gross \& Becker, 2002:411; Pithouse et al., 1998:64; WarrenAdamson, 2007:172) also found that family counselling as therapeutic service was rendered to at-risk families on an on-going basis, which supports the finding in this study. The advantages of family counselling have also been confirmed in research (Gallagher, Smith, Wosu, Stewart, Hunter, Cree \& Wilkinson, 2010:130), where families to which child protection services were rendered indicated that they experienced service delivery by social workers in a more positive way if the whole family was involved.

Counselling regarding domestic violence is also regularly given as $34(58.6 \%)$ respondents often deliver this service and $10(17.2 \%)$ always. Research (Dong, Anda, Felitti, Dube, Williamson, Thompson, Loo \& Giles, 2004:778; Hazen, Connelly, Kelleher, Landsverk \& Barth, 2004:314; Semidei et al., 2001:12) points to an interdependence between substance abuse and domestic violence, while the presence of both these phenomena increases the risk of child abuse and neglect. The fact that respondents at family welfare organisations in this study regularly provide counselling with regard to domestic violence is therefore appropriate.

Marriage guidance is the only therapeutic service for which the distribution indicates that the service is rendered often $(27=46.6 \%)$ or seldom $(17=29.3 \%)$. A minority of respondents render this service always $(9=15.5 \%)$ or never $(3=5.2 \%)$. Although this service is rendered less regularly than other long-term therapeutic services, marriage guidance is considered by Fraser et al. (1997:145) as a common element in family preservation services. However in this study group marriage guidance was offered less regularly than other therapeutic services.

\section{- Other therapeutic services}

Fifty-six $(69.5 \%)$ respondents did not identify other therapeutic services that they rendered. One $(1.7 \%)$ respondent indicated that mediation was often done and one $(1.7 \%)$ that children were seldom counselled after the death of their parents.

\section{DISCUSSION}

In this study the focus was on family-centred services rendered by social workers at family welfare organisations in a specific region in South Africa. South African policy documents and legislation focus strongly on the importance of family preservation in order to prevent the statutory removal of children. However, there is uncertainty among social workers in this study group regarding the actual content of family preservation services, with regards to the purpose and nature of service delivery, as well as the types of services that should be rendered. Only a minority of the respondents had a clear perception of the content of family-centred preservation services that should be rendered, such as developing the skills of families and empowering families to make use of resources. 
Regarding the investigation into the extent of the delivery of family centred-services (educational and enabling, therapeutic, concrete services), it seems that as for educational and enabling services the focus is placed more sharply on the development of life skills (educational services) than on linking families to formal and informal resources (enabling services) such as play groups, day care and weekly support groups. Supplementary support is thus not offered to families, which means that the informal and formal networks of families are not expanded in order to break their social isolation.

With regard to therapeutic services, the fact that short-term family-centred services such as crisis intervention are rendered most often is ascribed in part to the large case loads. This, however, also means that intensive family preservation services, as described in the literature (Tracy, 1995), are not actually rendered, as one of the characteristics of this service is smaller case loads. Although crisis intervention is important in the delivery of family preservation services, a balance must be struck between crisis intervention and the delivery of longer-term services, especially as the prevalence of poverty means that families will need services in the longer term, and especially with regards to substance abuse and family counselling.

Only limited concrete services are delivered to families. In addition to the fact that organisations probably do not have the resources (finances, vehicles, manpower) to render concrete services, there is also ignorance about the importance of concrete services to promote family preservation. This means that one type of service considered as a vital aspect of familycentred services specifically and family preservation services in general is not delivered. It also means there is ignorance about the utilisation of paraprofessionals to promote family preservation, on the one hand, and the development of appropriate early intervention and prevention programmes, on the other.

Paraprofessional persons can be engaged for certain concrete services and attention should be devoted, for example, to the development of home visit programmes, where members of the community are trained to offer home visiting services in families' homes. In this way the social networks of families will be extended and social inclusion will be promoted.

Home visiting programmes also present a solution to the shortage of social workers as the social workers can coordinate the programmes, but do not need to render the service themselves. The implementation of home visiting programmes also complies with the approach of the developmental model in social work service delivery, as human and social capital is developed which can build the community's capacity and contribute to economic development in the long run.

\section{CONCLUSION}

South African policy documents promote family preservation as a strategy to avoid the removal of children from their families. Universities should therefore make provision for training in family preservation services in curricula in order to ensure that the requirements in policy documents are met. Social workers at family welfare organisations should also receive thorough in-service training in what family preservation entails, especially regarding the nature and extent of the different types of services that should be rendered to families. Service plans should make provision for the rendering of concrete as well as educational and therapeutic services, thereby ensuring that service delivery would cover all aspects of family preservation. The ways in which especially concrete services can be expanded should be investigated, as this type of service is an important way to build a relationship with families and to ensure cooperation. 
Although people power and heavy case loads in South Africa are factors that should be kept in mind when delivering services, it is evident that there is uncertainty and ignorance about what family-centred services entail, resulting in certain services not being rendered at all. The consequence could be that the services delivered do not give families the opportunity to overcome their stressors and that children could still be removed. The fact that there is uncertainty about the content of family-centred preservation services also means that the services rendered in this study group should not be seen as indigenous to the South African circumstances, since perceptions of what these services should entail are not clear. Only when there is proper understanding of what family preservation services entail will social workers be able to develop and implement services that are authentic to and just in the South African situation.

\section{REFERENCES}

AL, C.M.W., STAMS, G.J.J.M., BEK, M.S., DAMEN, E.M., ASSCHER, J.J. \& VAN DER LAAN, P.H. 2012. A meta-analysis of intensive family preservation programs: Placement prevention and improvement of family functioning, Children and Youth Services Review, (2012), doi:10.1016/childyouth.2012.04.002.

ARMSTRONG, C. \& HILL, M. 2001. Support services for vulnerable families with young children. Child and Family Social Work, 6(4):351-358.

BERRY, M. 1997. The family at risk. Issues and trends in family preservation services. Columbia: South Carolina Press.

BERRY, M., CASH, S.J. \& BROOK, J.P. 2000. Intensive family preservation services: an examination of critical service components. Child and Family Social Work, 5(3):191-203.

BROWN, M. \& NEKU, R.J. 2005. A historical review of the South African social welfare system and social work practitioners' views on its current status. International Social Work, 48(3):301-312.

CASH, S.J. \& BERRY, M. 2003. The impact of family preservation services on child and family well-being. Journal of Social Service Research, 29(3):1-26.

CASH, S.J. 2001. Family preservation services: the Casey Family - a chronology. Journal of Family Social Work, 6(2):43-54.

CHAFFIN, M., BONNER, B.L. \& HILL, R.F. 2001. Family preservation and family support programs: Child maltreatment outcomes across client risk levels and program types. Child Abuse and Neglect, 25(10):1269-1289.

COLE, E.S. 1995. Becoming family centered: Child welfare's challenge. Families in Society: The Journal of Contemporary Human Services, 95(3):163-172.

DAWSON, K. \& BERRY, M. 2002. Engaging families in child welfare services: an evidencebase approach to best practice. Child Welfare, LXXXI(2):293-312.

DE VOS, A.S., STRYDOM, H., FOUCHÉ, C.B. \& DELPORT, C.S.L. 2002. Research at grass roots $\left(2^{\text {nd }}\right.$ ed.). Pretoria: Van Schaik Publishers.

DEPARTMENT OF SOCIAL DEVELOPMENT. 2004. Draft Service Delivery Model for Developmental Social Services. Pretoria.

DEPARTMENT OF SOCIAL DEVELOPMENT. 2006. Integrated Service Delivery Model towards Improved Social Services. Pretoria.

Social Work/Maatskaplike Werk 2012:48(4) 
DONG, M., ANDA, R.F., FELITTI, V.J., DUBE, S.R., WILLIAMSON, D.F., THOMPSON, T.J., LOO, C.M. \& GILES, W.H. 2004.The interrelatedness of multiple forms of childhood abuse, neglect, and household dysfunction. Child Abuse and Neglect, 28(7):771-784.

FORRESTER, D., COPELLO, A., WAISSBEIN, C. \& POKHREL, S. 2008. Evaluation of an intensive family preservation service for families affected by parental substance abuse. Child Abuse Review, 17:(410-426).

FOUCHÉ, C.B \& DE VOS, A.S. 2005. Quantitative research designs. In: DE VOS, A.S., STRYDOM, H., FOUCHÉ, C.B. \& DELPORT, C.S.L. Research at grass roots for the social sciences and human service professions ( $3^{\text {rd }}$ ed.). Pretoria: Van Schaik Publishers, 132-143.

FRASER, M.W., NELSON, K.E. \& RIVARD, J. 1997. Effectiveness of family preservation services. Social Work Research, 21(3):138-153.

GAllaGHER, M., SMITH, M., WOSU, H., STEWART, J., HUNTER, S., CREE, V.E. \& WILKINSON, H. 2010. Engaging with families in Child Protection: lessons from practitioner research in Scotland. Child Welfare, 90(4):117-134.

GHATE, D. \& HAZEL, N. 2002. Parenting in poor environments: stress, support and coping. London: Atheneum Press.

GRINNELL, R.M. \& WILLIAMS, M. 1990. Research in social work: a primer. Itasca, Ill.: F.E. Peacock.

GRINNELL, R.M. 1988. Social work research and evaluation. Itasca,Ill.: F.E. Peacock.

HAZEN, A.L., CONNELLY, C.D., KELLEHER, K., LANDSVERK, J. \& BARTH, R. 2004. Intimate partner violence among female caregivers of children reported for child maltreatment. Child Abuse and Neglect, 28(3):301-319.

INTER-MINISTERIAL COMMITTEE ON YOUNG PEOPLE AT RISK. 1998. Report on the Pilot Projects. Cape Town: The Printing Press.

JACK, G. 1997. An ecological approach to social work with children and families. Child and Family Social Work, 2(2):109-120.

JONES, P.L., GROSS, E. \& BECKER, I. 2002. The characteristics of domestic violence victims in a child protective service load. Families in Society: The Journal of Contemporary Human Services, 83(4):405-415.

JUBY, C. \& RYCRAFT, J.R. 2004: Family preservation strategies for families in poverty. Families in Society: The Journal of Contemporary Human Services, 85(4):581-590.

KRUGER, S.P. 1996. Intensiewe gesinsinstandhoudingsdienste: riglyne vir 'n maatskaplikewerk-model ter voorkoming van substituutsorg. Stellenbosch: Universiteit van Stellenbosch. (DPhil proefskrif)

LIETZ, C.A. 2009. Examining families' perceptions of intensive in-home services: a mixed methods study Children and Youth Services Review, 31(12):1137-1345.

LITTELL, J.H. \& TAJIMA, E.M. 2000. A multilevel model of client participation in intensive family preservation services. Social Service Review, 74(3):405-435.

LOMBARD, A. \& KLEYN, W.C. 2006. Statutory social services: an integral part of developmental social welfare service delivery. Social Work/MaatskaplikeWerk, 42(3/4):213233. 
MacDONALD, G. 2005. Intervening with neglect. In: TAYLOR, J. \& DANIEL, B. (reds) Child neglect: practical issues for health and social care. London: Jessica Kingsley Publishers: 279-301.

MALUCCIO, A.N., PINE, B.A. \& TRACY, E.M. 2002. Social work practice with families and children. New York: Columbia University Press.

MARTENS, P. 2009. IFPS toolkit. National family preservation network, 1-42.

MINISTRY FOR WELFARE AND POPULATION DEVELOPMENT. 1997. White Paper for Social Welfare. Government Gazette, 386 (18166). Pretoria, 8 August.

MULLINS, J.L., CHUENG, J.R \& LIETZ, C.A. 2011. Family preservation services: incorporating the voice of families into service implementation. Child and Family Social Work. [Online] Available: http://onlinelibrary.wiley.com/doi/10111/j.1365-2206.200.00777 ¿X/full. 2011.00777.

NAIR, S., BLAKE, M.L. \& VOSLER, N.R. 1997. Multilevel social systems practice with lowincome families in Singapore. Families in Society: The Journal of Contemporary Human Services, 78(3):291-298.

O'REILLY, R., WILKES, L., LUCK, L. \& JACKSON, D. 2010. The efficacy of family support and family preservation services on reducing child abuse and neglect: what the literature reveals. Journal of Child Health Care, 14(1): 82-94.

PARTON, N.E. \& MATHEWS, R. 2001. New directions in protection and family support in Western Australia: a policy initiative to re-focus child welfare practice. Child and Family Social Work, 6(2):97-113.

PECORA, J., FRASER, M.W., NELSON, K.E., McCROSKEY, J. \& MEEZAN, W. 1995. Evaluating family based services. New York: Hawthorne.

PIERSON, J. 2002. Tackling social exclusion. London: Routledge.

PITHOUSE, A. \& TASIRAN, A. 2000. Local authority family centre intervention: a statistical exploration of services as family support or family control. Child and Family Social Work, 5(4):129-141.

REPUBLIC OF SOUTH AFRICA. 2005. Children's Act: No 38 of 2005 Government Gazette, 492 (28944). Pretoria: Government Printers.

REPUBLIC OF SOUTH AFRICA. 2007. Children's Act: No 41 of 2007 Government Gazette, 513. (30884). Pretoria: Government Printers.

RUBIN, A. \& BABBIE, E. 2007. Essential research methods for social work. California: Thomson Brooks/Cole.

RYAN, J.P. \& SCHUERMAN, J.R. 2004. Matching families with specific family preservation services: a study of service effectiveness. Children and Youth Services Review, 26(4):347472.

SEMIDEI, J., FEIG-RADEL, L. \& NOLAN, C. 2001. Substance abuse and child welfare: clear linkages and promising responses. Child Welfare, $\operatorname{LXXX(2):109-128.~}$

SEPTEMBER, R. \& BLANKENBERG, C. 2004. A quest for excellence in multidisciplinary child protective services: an exploratory review. Cape Town: Child and Youth Research and Training Programme, University of the Western Cape, Printwize. 
SEPTEMBER, R.L. 2007. Separating social welfare services and social welfare grants: challenges and opportunities. Social Work/Maatskaplike Werk, 43(2):93-105.

SMITH, M.K. 1995. Utilization-focused evaluation of a family preservation program. Families in Society: The Journal of Contemporary Human Services, 76(1):11-19.

STRYDOM, H. 2005. Sampling and sampling methods. In: DE VOS, A.S., STRYDOM, H., FOUCHÉ C.B. \& DELPORT, C.S.L. Research at grass roots for the social sciences and human service professions ( $3^{\text {rd }}$ ed.). Pretoria: Van Schaik Publishers, 192-204.

STRYDOM, M. 2010. The implementation of family preservation services: Perspectives of social workers at NGO’s. Maatskaplike Werk/Social Work, 46(2):192-208.

THOMPSON, R.A. 1995. Preventing maltreatment through social support: a critical analysis. Thousand Oaks, California: Sage Publications.

TRACY, E.M. 1995. Family preservation and home-based services. Encyclopaedia of Social Work $\left(19^{\text {th }}\right.$ ed.). Washington: NASW Press: 973-981.

VAN PUYENBROECK, H., LOOTS, G., GRIETENS, H., JACQUET, W., VANDERFAEILLIE, J. \& ESCUDEROS, V. 2009. Intensive family preservation services in Flanders: an outcome study, Child and Family Social Work, 14 (222-232). doi.111/j.13652206.2009.00626.x

WARREN-ADAMSON, C. 2006. Research review. Family centres: a review of the literature. Child and Family Social Work, 11(2):171-182.

WEYERS, M., STRYDOM, H. \& HUISAMEN, A. 2008. Triangulation in social work research: the theory and examples of its practical application. Social Work/MaatskaplikeWerk, 44(2):207-222.

WILSON, D. \& HORNER, W. 2005. Chronic child neglect: needed developments in theory and practice. Families in Society: The Journal of Contemporary Social Services, 86(4):471481.

Dr Marianne Strydom, Department of Social Work, University of Stellenbosch, Stellenbosch, South Africa. 